Katia Guimarães

Programa Nacional de DSTe AIDS do Ministério da Saúde

\author{
Edgar Merchán-Hamann \\ Universidade de Brasília
}

\title{
Comercializando fantasias: a representação social da prostituição, dilemas da profissão e a construção da cidadania
}

Resumo: O presente artigo discute fatos, percepções e representações sociais do cotidiano das mulheres profissionais do sexo (MPS). Foram avaliados oito projetos de intervenção educativa sobre DST/Aids dirigidos a MPS, em cidades das regióes Sul, Nordeste e Sudeste. Foram realizadas entrevistas em profundidade e grupos focais. Os resultados revelaram que a representação da mulher que vende o corpo vem sendo re-significada para a realização de fantasias eróticas. As perspectivas de maior autonomia da profissão contrastam com a discriminação e a pressão psicológica. Foi mencionada a violência, praticada por clientes e policiais. Foram evidentes a importância do preservativo na negociação dos programas e o não-uso do mesmo em relações com envolvimento afetivo ou devido à concorrência. Conclui-se, sob a ótica da autonomia, que classe social, escolaridade, situação de crise econômica e estigma ocasionam discriminação, violência e risco de contágio de DST e HIV.

Palavras-chave: sexo comercial, cidadania, HIVIAids, vulnerabilidade, representações.

Copyright (c) 2005 by Revista Estudos Feministas
A p rostituição constitui-se como uma prática milenar que tradicionalmente tem subvertido o exercício 'controlado' da sexualidade via instituições sociais. Tentativas de controle foram implementadas no passado, variando da satanização, isto é, o controle exercido pela instituição religiosa, passando pela proibição expressa em códigos civis, e chegando, finalmente, nos dias atua is no Brasil, à demanda pela sua legalização, como atividade profissional.

Foi construíd o um vínculo, mais meta fórico do que factual, entre a prostituição e a transmissão de Doenças 
${ }^{1}$ VIANNA e LACERDA, 2004, p. 63.

${ }^{2}$ Eliza beth FEE, 1988, p. 131.

${ }^{3}$ Sérg io CARRARA, 1994, p. 77.

${ }^{4}$ J ohan KREISS, Davy KOECH, Francis PLUMMER, King HOLMES, Marilyn LIGHTFOOTE, Peter PIOT, Allan RONALD, Josiah NDINYAACHOLA, Lourd es D'C OSTA, Pacita ROBERTS, Elisa beth NGUGI e Thomas QUINN, 1986, p. 417; e Peter PIOT, Francis PLUMMER, Marie-Anne REY, Elisa beth NGUGI, Christine ROUZIOUX, Josiah NDINYA-ACHO LA, Gaby VERAC AUTEREN, Lourd ES D'COSTA, Marie LAGA, Herbert NSANZE, Lieve FRANSEN, David HAASE, Guido VAN DER GROEN, Robert BROUHAM, Allan RONALD e Françoise BRUN-VÉNIZET, 1987, p. 1111.
Sexualmente Transmissíve is (DST). Tal fato foi o motivo principal de práticas repressivas exercidas pelo Estado e implementadas com o auxílio do escrutínio sistemático efetuado pelas autoridades de saúde com o reforço de instituições policia is.

O exercício da prática independente da prostituição nã o é ilega I no Bra sil. Contudo, subterfúg ios lega is, ta is como o atentado ao pudor ou o escândalo público, têm sido utiliza dos como álibis para o enquadramento legal do exercício da prostituição.

Adriana Viana e Paula Lacerda chamam atenção para o fato de que, no que concerne à discussão sobre direito e polític as públic as volta das para a prostituição, não se pode perder de vista a s questões lega is específic a s que circ unsc revem os diferentes Sujeitos de direito que possam estar envolvidos na cena do comérc io sexual: homens, mulheres, crianças e adolescentes. As autoras enfatizam que "essa diferenciação incide tanto sobre o modo pelo qual se compreende a criminalização das atividades ligadas à prostituição, quanto sobre os tipos de ações em relação aos indivíduos que exercem a prostituição". ${ }^{1}$

No passado, ta nto no Brasil qua nto em outros países, no plano do cuidado com a saúde doshomens, o advento das doenças venéreas, princ ipa Imente a sífilis, para a qual não havia medic ação curativa eficaz, trouxe a necessida de da implementação de uma intervenção profilática em que foi focalizada, nesse sentido, a prostituição. ${ }^{2}$ Esse fa to fomentou o debate entre partidários do neoregulamenta rismo e os do abolicionismo (liberal ou proibicionista) e, ao mesmo tempo, norteou a política sanitária implementada então no Brasil para o combate à p rostituição. Deste modo, a s doença svenérea sjustific a ram a repressão, tendo como base discursiva a medicina higienista que fundamentava seus pressupostos na busca do bem-estar da população. ${ }^{3}$

Ta is temores e práticas discriminatórias em relação às prostitutas retomam à cena social com o advento da epidemia de Aids. Ao longo da década de 1980, quando asca racterísticas epidemiológ ic as da doença foram sendo conhecidas, e principalmente a partir da constatação de a ltas preva lências do HIV em cidades a frica nas, em loca is de comércio e em grandes estradas do interior dos países desse continente, a prostituta foi agregada ao quadro, definido originalmente como "grupos de risco": homossexua is, portadores de hemofilia, usuários de droga intra venosa e haitianos. ${ }^{4}$

Se por um lado os debates sobre a prostituição tinham se localiza do, pelo menos porum século, na tensão entre a perspectiva regulamentarista e a abolicionista na 
${ }^{5}$ Martha NUSSBAUM, 2002, p. 28.

${ }^{6}$ Ana Paula PORTELA, 2003, p. 8.

${ }^{7}$ Ric ha rd PARKER, 1994, p. 88; e Carlos Artur PASSOS, 2003, p. 23.

${ }^{8}$ Denise SERAFIM, Gabriela SILVA, José Lamir SANTANA, Ka tia GUIMARÃES, Liliana PITTALUGA e Roberto DOMINGUES, 2002.

${ }^{9}$ Richard PARKER e HerbertDANIEL, 1991, p. 13. disputa pela forma mais eficaz de intervenção social para o controle da sífilis, por outro, situa do no campo político, o exercício da prostituição foi considerado, sobretudo pelo movimento feminista e por setores anticapitalistas, como uma forma de mercantilização e de exploração da sexualidade da mulher, em que seu corpo é transformado em objeto para uso e controle dos homens, conseqüência da dupla moralidade, característica do patriarcado..$^{5} 0$ fenômeno do tráfico de mulheres e de crianças para fins de exploração sexual comercial e do turismo sexual também vem compondo o campo das preocupações feminista s. ${ }^{6}$

O surgimento da epidemia de Aids no Brasil, nos primeirosanos da déca da de 1980, entendido entã o como fenômeno associado a "grupos de risco", coincide com um período de grande mobilização dos diferentes movimentos sociais nas ta refas de restabelecer a democracia e buscaro exercício pleno da cidadania para a população brasileira, a pós 20 a nos de ditadura militar. ${ }^{7}$ Com efeito, pode-se considerar que é no bojo dessa mobilização que também se iniciou a luta pela conquista dos direitos civis e políticos das mulheres prostitutas. Os princípios políticos estabelecidos pelo movimento organizado de prostitutas afirmam-se a partir da autorepresentação e da autodetermina ção. Atualmente, esse movimento consolidou a legalização da profissão, como prioridade em sua agenda política. ${ }^{8}$

Nesse contexto, a inclusão da discussão sobre a epidemia de Aids na agenda do movimento de prostitutas não somente integrou esse segmento no processo de desconstrução do recrudescimento das respostas socia is de discriminação e de preconceito dirigidas àspopulações específicas que compunham o rol dos "grupos de risco", como também contribuiu para que essas mulheres a rticulassem ações que buscaram neutralizar os efeitos excludentes do que Jonathan Mann, em 1987, chamou de Terceira Epidemia ou Epidemia das Reações Socia is. ${ }^{9}$ Desse modo, o movimento brasileiro de prostitutas integrou a questão do HIV/Aids na sua agenda política, tomando a síndrome como um fator importante a ser considerado no exercício da profissão. Com a politização da prevenção do HIV/Aids, esse movimento potencializou e ampliou, para a sociedade em geral, suas a ções políticas, no sentido de obter a legalização da profissão como um componente importante da estratégia para a a tenuação dosfatores que vulnerabilizam o grupo para a doença.

Por outro lado, a resposta bra sileira à complexa crise gerada pelo advento da Aidsconsiderou a prevenção entre populações especialmente vulnerá veis como uma 
${ }^{10}$ Marga reth RAGO, 1996, p. 51.

preoc upa çã o perma nente das instânc ia s govema menta is. O Programa Nacional de DST/Aids (PN DST/Aids), seguindo os entendimentos intemaciona is sobre a doença, incluiu as prostitutas como um dos coletivos com necessidades específicas. Com esse entendimento, o PN DST/Aids direcionou seu trabalho à a mpliação de conhecimentos, desenvolvimento de habilidadespara negociação do sexo mais seguro, disponibilização de preservativos e apoio às ONG que ag em junto a o comércio sexual e às associações de prostitutas. Vale destacar que, desde então, as ações de prevenção das DST/HIV/Aids realizadas funda mentalmente por mulheres prostitutas, somadas às pesquisas realizadas em nível nacional, vêm tentando a mplia ro conhecimento sobre a rea lidade da prostituição feminina no País.

Pode-se dizer que a retomada do debate sobre a prostituição sob o efeito cataliza dor da epidemia da Aids acontece no contexto de um cenário político signific a tiva mente diferencia do daquele em que se deram as discussões sobre o controle da sífilis. Nos dias de hoje, apesar de a prostituição a inda ser comumente pensada em sua associação com a marg ina lidade, há a explic itação de um disc urso que emerge da politização de quem exerce a prostituição, reivindic ando o direito de exercer a profissã o em condições dignas, com a garantia de direitos e 0 cumprimento de deveres. No entanto, em que pese a legitimidade das reivindicações do movimento de prostitutas, o debate da prostituiçã o como profissão exige reflexões amplas, não se restringindo somente a os processos lega is para inseri-la como uma categoria a ma is no sistema formal de trabalho. Vale a pena lembrarque a prostituição já está incluída no Código Brasileiro de Ocupações.

Por se tratar de um tema que aglutina outros tão espinhosos quanto ele próprio, os debates sobre a prostituição têm sido restritos a o ca mpo disc ursivo repressor sobre as chamadas sexualidades vagabundas, ${ }^{10}$ ao da vigilância sa nitária e ao da crimina lidade. Gera Imente, nas reflexões sobre o tema, são postas em relevo as suas carac terístic as deprecia tivas, quand o somem as linhas que demarcam as fronteiras entre a realidade daquelas que vivem os dilemas cotidianos para o exercício da prostituição e a existência de outros fenômenos inaceitáveis para sociedade como um todo, como é o caso do tráfico de mulheres, de crianças e adolescentes para a comercialização sexual, do turismo sexual, do agenciamento da prostituição, entre outros.

O debate sobre a legalização da prostituição está sendo posto atualmente para a sociedade desde que o Projeto de Lei (PL) 98/2003, de autoria do deputa do Femando 
11 Assegura o direito à carteira assinada, aposentadoria, assistência médico-hospitalar e outros benefícios.
Gabeira, foi apresentado a o Congresso Nacional, encontrando-se em tramitação. O objetivo do PL é assegurar as condições de remuneração dos serviços prestad os, ${ }^{11}$ buscando garantir os direitos das prostitutas.

No entanto, para integraresse debate é preciso que se tenha em perspectiva, pelo menos, uma questão: a constituição das prostitutas como Sujeitos de Direito vem tomando dimensão significativa na medida em que elas se organiza ram politicamente em tomo da reivindicação pelo direito de exercer a profissão de forma digna, sem serem perseguidas. Entretanto, surge uma pergunta: há conhecimento suficiente sobre os dilemas que atingem o cotidiano dessas mulheres para que se possam identificar os limites que separam a prostituição das prátic a s que são percebidas como indissociáveis a ela, como é o caso do tráfico de mulheres e a exploração sexual de crianças e a dolescentes?

Nesse sentido, este artigo, resultado de um dos investimentos na área de pesquisa e produção de conhecimento sobre o tema, constitui uma tentativa de contribuir para a discussã o sobre aspectos factua is, percepções e representações em relação ao cotidiano das mulheres prostitutas. Ele destaca a nova concepção que essas mulheres possuem de sua atividade profissional (o comércio de fantasias); os dilemas enfrentados no diaa-dia derivados do estigma a elas dirigido (a violência do meio e seus agentes, a inclusão do sexo mais seguro na negociação do programa, as contradições nas relações com os clientes e com os parc eiros a fetivos, as dific ulda des enfrentadas na vida íntima); e a busca da vivência cidadã como elemento principal na prevenção da epidemia do HIV/Aids nesse segmento.

\section{A fonte da reflexão}

Os depoimentos utiliza dos neste artig o fora m obtid os a partirda realização de um estud o que avaliou oito projetos de intervenção educa tiva sobre DST/Aids direciona dos para mulheres prostitutas, desenvolvidos em cidades pertencentes a três estados da macro-região Sul, três da Nordeste e três da Sudeste. Tanto a escolha das regiões quanto das cidades se deu, fundamentalmente, a partir do perfil epidemiológico da Aidsentre as mulheres, da maior concentração de á reas de prostituição e, porconseguinte, da presença de maior concentração dos projetos de prevenção do HIV/Aids dirigidos para as mulheres desse segmento.

O trabalho de campo foi realizado no período de outubro de 2000 a março de 2001 . Em todos os sítios, as 
multiplicadoras vinculadas aos projetos foram as responsáveis pelo recrutamento das prostitutas partic ipantes. Foram rea liza da sentrevista sem profund id a de e grupos focais conduzidos por pesquisadores e pesquisa doras integrantes do Núc leo de Estud os em Saúde Pública (NESP), da Universida de de Brasília (UnB). O protocolo de investigação foi a preciado e a prova do pelo Comitê de Ética em Pesquisa da Faculda de de Ciências da Saúde da UnB.

A seleção dos projetos foi realizada com base em a lguns critérios previamente definidos, ta is como a a tua ção direta junto à s prostituta s em contextos urb a nos e no interior das regiões selecionadas e ações em contextos diferenc ia dos de prostituição. Além desses critérios, ta mbém fora m observa dos tempo de dura ção dosprojetos, caráter de continuidade e a cobertura dos mesmos. Dos oito projetos selecionados, seis eram conduzidos por ONG, um por uma universidade privada, e um outro por uma Organização Governamental.

Como critérios gera is, que deveria $m$ ser preenchid os pelas mulheres partic ip antes do estudo, fora $m$ definidos a idade mínima de 18 anos e tempo de exercício da prostituição, bem como de participação no projeto de, no mínimo, seis meses. As prostitutas abordadas para responderem à entrevista e para integrarem os grupos foca is só o faziam após lerem e assina rem um termo de consentimento livre e esclarecido.

\section{Contribuição teórica}

A narrativa histórica sobre a prostituição confere a identidade social da mulher prostituta como sendo construída a partir da sua condição de transgressora das regras e normas estipula das socia Imente para o exercício da feminilidade. Nesse sentido, tanto a construção do estigma em relação a o exercíc io da prostituição, bem como os mecanismos de respostas socia is de discriminação e preconceitos, decorrem da sucessão de fatos históricos, nos quais a prostituta foi responsabilizada pela disseminação de doenças adquiridas pelo ato sexual.

Um exemplo claro desses fatos históricos refere-se a os pressup ostos vincula dos a os id ea is higienistas, em que a prostituta foi considerada como uma ameaça para a construção da família no contexto das expectativas da edific ação do Estado. Nesses termos, as mulheres envolvidas na prática da prostituição foram categorizadas como responsáveis pela degradação física e moral dos homens e, por extensão, pela destruição das crianças e famílias. Ademais, elas pervertem, com o exemplo 
12 Denise SERAFIM, Gabriela SILVA, J o sé Lamir SANTANA, Ka tia GUIMARÃES, Liliana PITTALUGA e Ro berto DOMINGUES, 2002, p. 41.

${ }^{13}$ Denise SERAFIM, Ga briela SILVA, José Lamir SANTANA, Ka tia GUIMARÃES, Liliana PITTALUGA e Roberto DOMINGUES, 2002.

${ }^{14}$ Erving GOFFMAN, 1988.

15 GOFFMAN, 1988; e Pierre BOURDIEU, 1999. desregrado de suas vidas públicas e do exercício de sua sexualidade, a moral da mulher-mãe, cuida dora, restrita à vida privada do lar. ${ }^{12}$

Não obstante, o reflexo resultante da conjugação desses fa tos históric os trouxe a consolidação de um senso comum em que a prostituta passou a ser representada como sendo uma mulher desprovida de alguns traços ma is distintivos do gênero feminino. É como se nela estivesse incorporada uma anomalia no sistema de gênero: a mulher que possui uma maneira peculiar de exercer a sua sexualidade, ou seja, o faz de forma pública é desprovida de laços a fetivos e, pelo fato de experimentar o sabor da transgressão sexual, não é merecedora da vivência conjugal, familiare, sobretudo, da matemidade. ${ }^{13}$

Esse modo de representar a mulher prostituta, a tribuindo-Ihe característic as transgressoras, presentes no senso comum, incide na percepção que ela faz de si mesma. Ao mesmo tempo interfere nas interações que ela terá, seja no momento de exercer a profissão, seja no momento de buscar serviços médicos ou mesmo em diferentes âmbitos da vida íntima e social.

Muito embora o estigma seja experimentado, no caso em questão pelas prostitutas, de forma subjetiva, é importante ressaltar a sua construção coletiva. Nessa perspectiva, o estigma pode ser considerado como dispositivo de controle cujo objetivo é a manutenção, em a lguns grupos que exibem uma diferença indesejável, do sentimento de menos-valia social imputado a eles. Essa percepção determina inexoravelmente a sua desqualific ação como Sujeitos de Direito que, a o mesmo tempo que vêem negada a sua cidadania, negam-se a conquistá-la. O registro negativo imputado pelo estigma provoca o que Enving Goffman descreveu como identida de deteriorada. ${ }^{14}$

É mediante essa referência de pertinência que irá se estruturar e condicionar as relações de quem é estig ma tiza do com o mundo, de forma geral. Por intermédio do processo dinâmico produzido entre a sociedade e o sujeito estigmatizado, essa menos-valia é reforçada, transformando o estigma em algo naturalizado. E nesse contexto de banalização do processo de estigmatização são erigidas as mais intransponíveis relações de desigualdades socia is. Cabe ta mbém acrescentar que o processo de construção social do estigma pode ser considera do como uma estra tégia de manutenção de uma ordem de poderque se pretende hegemônico, em que a díade dominação-sujeição concretiza os imperativos sociais vigentes, seja pela coerção, seja pela violência física ou simbólica. ${ }^{15}$ 
${ }^{16}$ NUSSBAUM, 2002, p. 15.

${ }^{17}$ FREITAS, 1985, p. 12.

${ }^{18}$ Howard BEC KER, 1963.
De acordo com Martha Nussbaum, ${ }^{16}$ em todas as profissões se ganha dinheiro com o uso do corpo, realiza ndo coisa s com partes dele, havendo remuneração para isso. Em a lguma s profissões se rec ebem bons salá rios, em outras não; algumas possuem um bom controle sobre as cond ições de tra ba lho, outra s não. Alguma s profissões são estigmatizadas, enquanto outras não. A estigmatiza ção vincula da a a lguns exercícios profissiona is é decorrente de reaçõessociaisde preconceito seja de classe, seja de raça ou de gênero. No entanto, a autora ressalta que a té mesmo o estigma pode sofrer rápida transformação quando mudam os costumes elementares e, por conseguinte, as reações soc ia is de preconceito liga dos a ele, ou seja, para compreender o fenômeno da prostituição é necessário sempre contextualizar a sua definição, tendo em vista a ordem sexual, os padrões de moralidade, de normalidade, de conjugalidade e das ideologias vigentes.

Nussbaum destaca dois fa tores que persistem como fontes do estigma dirigido às prostitutas: um que associa intimamente a prostituição a um amplo leque de moralidades, tornando-a, conseqüentemente, uma experiência imoral. O outro amarra a prostituição às representações hierárquicas de gênero e à idéia de que as mulheres e sua sexualidade precisam da dominação e controle masculinos, ficando disponíveis à realiza ção dos desejos sexua is dos homens.

Segundo Renan Freitas, ${ }^{17}$ a perspec tiva intera cionista trouxe relevante contribuição para a compreensão da prostituição, do ponto de vista do comportamento desviante. ${ }^{18}$ A contribuição referida se dá na contextualiza ção da prática da prostituição, como o lugar da detecção de padrões de interação que permite revelar as diferentes realidades empíric as desse universo. 0 autor destaca que a utilização da abordagem interacionista permitiu a identificação de duas ordens mora is em interação: uma que se refere a o mundo da prostituição, e uma outra ligada ao mundo 'normal'. Essas duas ordens morais interagem e negociam rotinas, identidades, hiera rquias, sistemas de estra tific a ção, regras de convívio, etc. O olhar interacionista sobre a prática da prostituição permitiu o reconhecimento da pertinência do papel da negociação na construção de uma ordem social.

Nesse contexto, a negociação de rotinas, assim como a disputa pelo controle sobre a interação, implica a dmitir que ta mbém há uma comunic ação não cognitiva, ou seja, não verbal, em que a postura básica do cotidiano da vida das pessoas se estabelece por meio de compromissos tá c itos. Esses comp romissos são firma dos na convivência social a partir da repetição e ritualização da 
comunicação de expressões e significados, que comportam interp retações.

Ainda na perspectiva de Freitas, o programa é a unidade elementar da atividade da prostituta, pois se constitui no momento em se dá a negociação de rotinas, identidades e disputa pelo controle da interação com o cliente, ou seja, negocia-se o tempo do programa, seu preço e as práticas sexuais. O acordo negociado é quebrado quando um desses componentes do programa é rompido por uma das partes: prostituta ou cliente. Nos dias a tua is, tend o em vista a disseminação do HIV, inc lui-se nessa negociação o uso do preservativo.

\section{Comercializando fantasias}

Uma das fortes representa ções soc ia is relacionadas à prostituição e à prostituta, no senso comum de nossa sociedade, encontra-se vinculada à imagem da mulher que está presente em um espaço marginal reservado à continência dos desejos sexua is masculinos, livrando as moças de 'boa família' da voraz realização das nec essida des biológ ic as dos homens. Dura nte muitosa nos, a tolerância da prostituição como um 'mal necessário' determinou a forma pela qual asprostitutas se reconheciam no campo social. A imagem predominante, nesse sentido, era aquela que a tomava a mulher que vendia seu corpo no intuito de satisfazer as luxúrias masculinas que não podiam ser rea liza das no espaço da relação conjugal, ou mesmo antes do casamento.

No entanto, foi observado nos grupos focais que a representação social de uma mulher que vende o corpo para a sua sobrevivência vem sendo, em certo sentido, deslocada e re-significada, por ela, para novas interpretações sobre o erotismo presente na prostituição. Nesse contexto, pode-se perceber que a idéia da rea liza ção de fantasias eróticas, bem como de diferentes jogos sexuais que não se restringem à prática sexual convencional, vem se revelando como a razão da busca de muitos dos clientes pelo comércio de fantasias.

Eu acho que essa coisa de dizer que a gente vende o corpo é uma bobagem. Meu corpo está aqui comigo. Ecuido muito bem dele. A gente está a qui para vender fantasia, ilusão. Muitas vezes, tem uns clientes que nem querem nada, só conversar. E a gente conversa. Tem muita coisa misturada nessa coisa da prostituição. É só a gente não aceitar dizer essas coisas da gente. Isso é o que todo mundo pensa, mas ninguém na verdade sabe de nada. Eu não a ceito isso não (Rio Grande do Sul). 
Eu tenho um cliente que tem 47 anos, e é casado há quase 20 anos, e ele vai pra boate e traz uma pasta, que ninguém sabe o que tem na pasta, ele tem um chic ote e um vibrador, e a quele cintinho que aumenta (Minas Gera is).

Uma vez eu fizum programa com uma mulherque mora lá na pensão onde eu moro. Era o cara e nós duas. Daí o cara queria ver nós duas transando. Então tá né... Eu fui. Mas eu não gosto não. Daí o cara pagou, e pagou bem, eu saí de lá cheia de dinheiro. Aí eu pensei, se eu tô nessa vida tenho que fazer isso mesmo. Daí pintou outro programa, eu me soltei mais. Aí, hoje em dia normal (São Paulo).

\section{A profissão e os seus dilemas}

Em relação a o grau de satisfação com a profissão, a parece a divisão entre a possibilidade da liberdade e da autonomia na administração do horário e as condições do trabalho, como ta mbém maiores ga nhos financ eiros em contra ste com a disc rimina ção deriva da do estigma, e com a pressão psicológica e emocional, originada da necessidade de se encobrir o exercício da prostituição, o que é revelado pela maioria das participantes da pesquisa. Além disso, também foram mencionados alguns riscos envolvidos no cotidiano da atividade.

É um trabalho como outro trabalho qualquer. A diferença é que, para a sociedade, nós somos colocadas à margem, só que para a nossa realidade não é nada disso. 0 trabalho que nós realizamos ali é um serviço de utilidade pública. Por quê? Porque, se não fossem as trabalhadoras do sexo, nós, o que ia ser lá fora? (Rio de Janeiro).

Pra mim eu já acho uma vida difícil. Eu estou nisso porque preciso, tenho três filhos que precisam de mim. E trabalhar em casa de família paga pouco demais. Então eu acho que fazendo programas ganha mais, agora só eu não gosto. Acho difícil porque nunca me acostumei com a vida, é só uma questão de necessidade mesmo (Pa raíba).

Entre os riscos, a violência praticada por alguns clientes aparece, em todos os grupos, como um fator de tensão permanente também oriundo do estigma. Essa violência se manifesta nas formas de a meaça com arma, agressã o verbal, físic a e/ou moral.

Primeiro eu fiz assim, eu tinha um cliente que saia comigo... que ele puxou a arma dentro do carro para mim, e eu não pude fazernada. Me deixou larga da na rua, eu não sa bia nem como sa ir da quilo a li, não sa bia 
nem onde eu estava... minha sorte foi que um taxista me viu lá, me pegou e levou. Eu não tinha dinheiro para pagar, peguei uma carona com o taxista, porque nem táxi não passa va no local. Mesmo com cliente eu tenho medo, agora só vou para perto (Rio de Janeiro).

Um cliente me falou me dê um beijo e quando eu fui beijar ele tascou um tapa na minha cara (Sergipe).

Eu mesma saí com um cara um dia, ele tava me tocando muito, me machucando muito. Tava ruim que não eu tava agüentando, aí eu comecei a suar, e quando eu peguei a toalha assim para me limpar ele falou assim: puta tem que suar mesmo (São Paulo).

Há ta mbém rela tos de violênc ia físic a pratic ada pela polícia. Agrega-se a esse tipo de injúria a a ção a rbitrária e a busiva feita por policia is, além do roubo e da extorsão.

Humilham a gente [os policiais], chamam a gente de vagabunda, que é pra trabalhar... A gente fala que não tem emprego. Aí eles falam: isso é problema de vocês, se virem; vocês têm quinze dias pra arrumar emprego senão vão pra penitenciária... nós vamos marcar a cabeça de vocês e vocês vão tirar uns seis meses... (Paraná).

Não lá na praça lá, eles vão tipo assim... 7 horas que daí eles começa. 7 horas, 6 e meia lá na praça. Que daí eles sabem que as meninas já têm o dinheiro e tudo. E daí se tiver 5 reais eles pegam, tiram da bolsa da gente e fic a pra eles. A maioria do policial fazassim (Paraná).

Era cana todo dia. Os brigadianos - eram civis - uma vez eles pegaram a gente em três micros, pegaram todas as mulheres de Porto Alegre e largaram a gente na llha Pintada, não levaram para a delegacia nem nada. Assaltaram, tem umas que eles bateram com cacetete, botaram na genitália (Rio Grande do Sul).

\section{Rotina e condições de negociação do programa}

\section{0 cliente}

Em todos os grupos e em todos os tipos de orga niza ção da a tivida de, a pa rece a mesma c la ssific a ção da c lientela, destacando-se o cliente comum, que é o ma is freqüente, como aquele que, a certada a negociação, faz o programa, paga o combinado e não cria problemas. 0 mau cliente é aquele que ofende, ou tenta burlar e/ou desc umprir o programa combinado ou o preço negociado, ou ainda ameaça ou agride. O bom cliente é o que trata 
bem ou é carinhoso, não se vale do estigma para negociar o programa, para ofender ou agredir as mulheres.

Eu acho que o bom cliente é aquele que me trata bem, não me maltrata, não me magoa, aí eu acho ele um bom cliente para mim.. me dá carinho... porque tem uns que chegam humilhando a gente, dizendo coisas; se é para humilhar eu digo também, não fico calada não (Paraíba).

O c liente fixo é aquele que só proc ura poruma mulher, e o faz regula rmente. Há ta mbém o cliente que faza miza de, sendo que o relacionamento com ele fica no limiar entre 0 profissional e o a fetivo.

Ecada uma já tem seus clientes certos, eu tenho c lientes de 15 anos, desde o dia que eu comecei até hoje. Tem uns que eram solteiros, já casaram, têm filhos, já casaram de novo, estão sempre lá (GFI - Rio Grande do Sul).

Eu tenho muitos fixos, que preferem só comigo do que com outras meninas ma is bonitas (Minas Gerais).

\section{O programa}

Foram mencionados os seguintes aspectos envolvidos na negociação do programa: tipo de prática a ser atendida; o preço; conforme o caso, o local; e o uso do preserva tivo. Vale desta car que o não-uso da ca misinha é uma prática demandada por uma boa parte do segmento da clientela e implica, geralmente, um a dicional ao preço do programa.

O cliente chega e pergunta o preço pra uma e pra outra, pra verquem é mais barato. Uma fala 20 ele diz deixa por 10. Você fazanal? Chupa sem camisinha? Aí se você não faz, ele procura outra. Até que aparece um de 15 , ele paga 5 para o hotel e 15 pra mim, pra fazer normal, né? mas mesmo assim eles querem que chupe e ainda quera bundinha (São Paulo).

Trataré assim: ele fica olhando para a gente, com olho de cobra morta, aí eles dizem, você faz o programa por quanto, por 15, 20, aí eles dizem assim, tá caro, aí a gente fala, tá não, rapaz, a gente vai fazer gostoso. Aí ele diz, gostoso como? Rola uma bundinha, rola uma chupadinha? Aí depende da mulher, se ela topar, ela sobe com ele, se ela disser que não, ele já vai darem cima de outra. Tem umas que enjeita m 10, a outra quer. Já aconteceu de a gente estar assim... eles querem pagarcaro, 40 rea is, mas sem ca misinha; eu digo não, aí ele pergunta, quem é que transa a qui sem ca misinha? Eu digo não sei, procura aí, porque até 20 eu aceito, mas com camisinha, só assim. Mas tem mulher que aceita (Paraíba). 
Em termos gerais, os grupos focais sinalizam que a habilidade de utilizar o preservativo não se constitui como um obstáculo para a adoção de práticas sexuais mais seguras nas a tivida des profissiona is. Segundo as integrantes dos grupos, não há mulher que batalha que não saiba colocar a camisinha em seu freguês. Relatam que os clientes, em algumas situa ções, tentam romper o acordo feito para a realização do programa, usando de subterfúgios para não usarem o preservativo. No entanto, as prostitutas a firmam que possuem estra tégias e recursos para impedir que ta is situações sejam recorrentes. O depoimento citado abaixo pode ilustra r essa afimação.

Tem unsque apagam a luze rasgam a ca misinha. Outro dia um fez assim, rasgou a camisinha, trek, e eu disse, vai ter que pagar a multa. A multa é de 5, 10, 15, dependendo do tamanho do estrago da camisinha (Paraíba).

Um aspecto relevante que pode influir, ou provocar tensão, na negociação do programa é o que as participantes reconhecem como a concorrência. Essa concorrência se toma mais a cirrada quando há algum tipo de alteração nas condições financeiras dos clientes. Quando isso acontece, o preço do programa é reduzido. Assim, são obrigadas a fazer um maior número de programas em função desse desequilíbrio nas finanças. Para conseguir aumentar o número de programas, elas, muitas vezes, necessitam flexibilizar na negociação por preço, práticas e proteção.

Desse ponto de vista a rua é péssima. Já foi bom, mas hoje em dia acho que é porque tem muito homem desempregado (São Paulo).

Tem uns freguesinhos que olha para a gente na rua e pergunta quanto é o programa? É 30, aí ele diz, porque você cobra 30 se a outra ali é 20 ? Porque não tem tabela. O preço dela é 20, o meu é 30 (São Paulo).

E sabe por que eles saem sem camisinha? A mulher acaba saindo sem camisinha? Porque aí o cara que não sai com camisinha, que é esse que não gosta de pôr camisinha, acaba chegando no preço mais alto, entendeu? Aí a mulher que precisa, que às vezes não faznada durante o dia, aía parece uma oportunidade ma is cara, acaba fazendo (Paraná).

A idade da prostituta é considerada, por elas, como um dado do perfil que exerce grande influência, no âmbito da concorrência pelo cliente, especialmente no momento de negociarem as condições do programa. As prostitutas relatam que essa interferência pode acontecer tanto no 
grupo de mulheres com mais idade quanto no das ma is jovens. Elas informam que as mulheres com mais idade, que geralmente trabalham nas ruas, têm mais tempo de profissão e são vistas como tendo ma is experiência no ofíc io, porém muitas vezes são preteridas por clientes que preferem mulheres ma is jovens e não exigem a experiência sexual como condição para a realização do programa. Nesse caso, quando a competição se toma elevada, o número de clientes e o preço do programa diminuem e elas encontram extrema dificuldade em negociar favoravelmente o programa, tanto em termos de práticas ma is seguras quanto em termos de preço. Essas mulheres, para garantir a sobrevivência mínima, muitas vezes são levadas a flexibilizara negociação do programa, e o fazem justamente abrindo mão da segurança em relação à própria saúde, não utilizando o preservativo.

Quando a gente tem mais idade é mais difícil. As meninas novas não tem a mesma coisa na cabeça da profissã o. Acho que nós a qui não é a ssim nem quando era quem nem que elas. As casas só querem meninas porque traz ma is freguês, ma selas não conversa m com o freguês que nem a gente conversa. Mas elesquerem a beleza... Na rua não é muito bom não, aqui elas chegam [as mulheres mais jovens] e fic am e a gente tem que baratear o programa, arriscar a vida para conseguir levaralguma coisa para casa. A rua mesmo não é de ninguém (São Paulo).

Segundo as participantes do estudo, quando os c lientes procuram pela experiência na prática da profissão, sã 0 as mulheres ma is jovens que nec essita $m$ reduziro preço do programa ou mesmo realizá-lo sem o uso de preservativo.
Sabe por que está ruim a vida na rua? Porque as mulheres novas não se va lorizam, muitas vão por 5 rea is. O homem passa e fala, vamos fazer um programinha? Quanto? É 15, 20, é muito, ali naquele outro lugar elas fazem por 5. Nossa, a gente fica lá embaixo. Caiu, o que tem de mulher fazendo por 5, é uma coisa verg onhosa, horível. Principalmente, a quela s meninas ali [referência a um ponto de prostituição], aquelas meninas bem novinhas, tudo cobrando 5 (Paraná).

Um outro fa tor que está envolvido no uso consistente do preservativo refere-se à a fetividade. Em todosos grupos, houve participantes que mencionaram estabelecer, com signific a tiva freqüência, vínculos a fetivos no a mbiente de trabalho. Nessas condições, passam a prevalecer os critérios do relacionamento a fetivo no que diz respeito à flexibiliza ção do uso do preservativo, mesmo quando essas relações se limitam à a mizade. 
Sabe o que eu fiz? Eu trabalhava no hotel..., aí todo o dia um rapaz ia lá. Aí nós começou a namorar, namoramos. Aí eu comecei a pegaramiza de com ele, e nós começamos a transar sem camisinha. Aí engravidei dele e nunca mais eu vi ele (Paraíba).

Outra coisa que eu acho errado, tem mulher que é assim, quer ver? Você arranja um namorado hoje, aí você transa com ele, dali uma semana, meu amor, minha vida, beijo para lá, beijo pra cá, aí transa sem camisinha com ele. Aí daí um mês você vai e separa dele, a ruma outro namorado, mesma história, sem camisinha com ele. Não a dianta nada você se prevenir no hotel e lá fora você transar sem camisinha, não adianta nada ( Minas Gerais).

Com ele é sem camisinha. Já vai fazer o quê? Sete anos... Desde o começo da batalha que eu saio com ele sem camisinha. Mas ele chega ali no passeio, ele não sai com mulher nenhuma. As meninas mesmo fala: mas esse é honesto, né? Mascomo é que eu vou saber? Só Deus mesmo pra saber. Porque tem muitas mulher lá pra cima... Eu vou saber? Às vezes não faz isso com medo de contar pra mim, né? Vou saber lá do outro canto? Dá pra confiar? (Paraná).

Aind a no contexto das disc ussões sobre a fetivida de, em todosos grupos, quando se tra tava do rela ciona mento com companheiros e namorados, houve manifestações quase que unânimes do não-uso do preservativo. 0 nãouso da ca misinha na srela ções está veis a pa rece justific a do, ora pela insa tisfa ção do companheiro em utilizá-la, ora por não ser necessário nas práticas sexuais conjugais. Os depoimentosque se seguem podem sugerirque a dispensa do uso da camisinha seja um marco simbólico diferencia dor entre as práticas sexua is profissiona is daquela sque se dão no contexto das relações a fetivas sexuais.

Eu só não uso camisinha com o meu parceiro, mas com o cliente sempre... (Rio Grande do Sul).

Pesquisador: Gente, e com o namorado, vocês usam camisinha?

- Eu não, com o meu não.

- Eu também não, ele não gosta.

- Quando o meu era vivo eu usava.

- De vez em quando eu uso...

- Com o meu eu não uso não, ele me xinga, já vem com isso...

- O meu não aceitava não, tem vez que eu ponho a camisinha lá em cima da cama assim, ele, para que isso? Para você usar. Não, de jeito nenhum. (Minas Gera is).

Fica chato, eu acho que tira a liberdade (Paraíba). 
19 Ka tia GUIMARÃES, Eurípedes DIAS, Ana Maria COSTA e João Marcos ANDRADE, 1997; Ka tia GUIMARÃES e João Marcos ANDRADE, 1999; Edga r MERC HÁNHAMANN, Maria EKSTRAND, Estie HUDES e Noma n HEARST, 2002; e Katia GUIMARÃES, Alcinda Maria GODOI, Edgar MERCHÁNHAMANN e João Marcos ANDRADE, 2004.

20 MANN e TARANTOLA, 1996, p. 433.

${ }^{21}$ Anthony GIDDENS, 1992.
E pinta a li na hora, você está no banheiro, na sala, na cozinha, no quarto, o casal não vai pegar camisinha. É, se for parar para pegar, perde o clima (Rio de Janeiro).

\section{A busca pela cidadania - a discussão associada à prevenção do HIV/Aids no contexto da prostituição feminina}

Este artig o buscou a presentar alguns aspectos que influenciam na proteçã o da s prostituta s em relação a o HIV/ Aids. São eles: os fatores sociais, econômicos e cultura is. Analisando os depoimentos pela ótica da autonomia na negociação dos programas e as vivências a ela associadas, percebe-se que o estigma para com a profissão ocasiona a discriminação, a violência e o risco de contá gio pelo HIV ou demais DST.

Além desses fa tores, o envolvimento a fetivo a parece ta mbém como um limitador da autonomia nas decisões relacionadas com a proteção no campo da saúde das prostitutas brasileiras, fa to este já referido em outras pesquisas sobre o tema. ${ }^{19}$ Atentamos para o fato de que aspectos de vulnerabilidade macrossocial e individual, apontados por Jonathan Mann e Daniel Tarantola, ${ }^{20}$ aparecem claramente nesta pesquisa. Porém, o fa to de a prostituta trabalhar em um contexto em que uma pretensa to lerância convive com o estigma intro duz um componente de vulnerabilidade ma is específico para esse coletivo.

Não há dúvida de que o advento da Revolução Sexual dos anos 1950 e 1960 trouxe uma maior emancipação e participação da mulherno âmbito social, no campo da sexualidade e no campo reprodutivo. Com o surgimento e difusão de métodos contraceptivos, as mulheres viram o exercício da sexualidade desvinculada da reprodução. ${ }^{21}$ As decisões, tanto no campo sexual quanto no reprodutivo, passaram a ser mediadas, então, pela autonomia conquistada. Com a crescente onda da emancipação sexual acreditou-se que a prostituição não mais teria a sua função no cenário das interações sexuais. Contudo, ela não só permaneceu na cena pública e nas disc ussões sob re as mora lida des existentes como ta mbém, com o passar dosa nos, diversific ou suas modalida des para a lém da prostituição tradicional das chamadas "zonas de tolerância" ou "zonas de meretrício", para os bares, cinemas, ruas e hotéis.

É importante destacarque a existência da epidemia de Aids revelou diferentes a spec tos das culturas dos grupos ou comunidades a fetadas por ela. Por outro lado, deu visibilida de a reivind ic ações socia is tra zidas por segmentos 
${ }^{22}$ NUSSBAUM, 2002, p. 13-55.

${ }^{23}$ Denise SERAFIM, Gabriela SILVA, José Lamir SANTANA, Ka tia GUIMARÃES, Liliana PITTALUGA e Roberto DOMINGUES, 2002, p. 17. da sociedade civil, tra dic ionalmente estigmatizados. E nesse sentido foi de grande importância o estabelecimento de diferentes conhecimentos do cotidiano, das vivências e dos jogos de cada uma dessas culturas.

No caso das prostitutas, cada nova dimensão galgada nesse conhecimento pode permitir o entendimento da cena da prostituição não mais como o locus do mal necessá rio ou mesmo das especulações em relação a sua causa lidade, massim c omo um espaço onde se estabelecem diferentes códigos de vivência e convivência, bem como de emoções e afetividades. A vivência coletiva e individual do estigma, demonstra da nas fa las das partic ipantes dos grupos foca is, expõe cla ra mente a experiência ambivalente vivenciada no exercício da prostituição. Se por um lado ela aparece como uma ocupação considerada rentável que proporciona uma maior liberdade, por outro tal experiência revela, talvez, uma série de comprometimentos derivados do processo de estigmatização em que vivem as prostitutas, dia após dia, tanto no espaço públic o qua nto no íntimo. A prostituta, cuja sexualidade é pública e não controlada, é vista como perigosa.

Nessa perspectiva, concorda mos com Nussbaum:22 em que pese as dificuldades oriundas do estigma para a vida dessas mulheres, há que se pensar na riqueza de códigos ou classificações existentes na cena da p rostituição. É a li que as prostitutas primam por orga niza ra forma de interação com os enfrentamentos postos para exercer a profissão.

Conforme os relatos a presentados, a prostituição é vista, por quem a exerce, como uma negociação comercial. Todavia, a inda persiste um senso e um julgamento vinculados ao "ganhar dinheiro" ou firmar contratos em relação ao uso das próprias capacidades sexuais e reprodutivas como uma prática depreciativa. Nesse sentido, os depoimentos chamam atenção para uma nova perspectiva para a prostituição: ela passa a ser um espaço de realização de fantasias. Segundo Dominguese colaboradores, ${ }^{23}$ é perseguindo experiências, basea das na ruptura com o sexo convencional e a tra vessadas pornovas e/ou proibidas sensações, que homens procuram o sexo junto às prostitutas.

Também é ressaltado que, no contexto da relação com os clientes, as interações estabelecidas e referidas pelas participantes da pesquisa variam das ma is comuns na profissão a té as ma is a fetuosas. Contudo, elas possuem a clareza de que essas interações são mediadas pela incidência do estigma que traz dilemas no contexto da negociação e na realização do programa. 
24 MANN e TARANTOLA, 1996, p. 464.

${ }^{25}$ Denise SERAFIM, Gabriela SILVA, José Lamir SANTANA, Ka tia GUIMARÃES, Liliana PITTALUGA e Roberto DOMINGUES, 2002, p. 21.
O fato de o estigma atuar no campo dessa mediação pode trazer conseqüências importantes para o campo de a tenção à saúde dessa smulheres, em particular no que diz respeito à negociação de práticas sexua is ma is seguras. Essa interferência foi mencionada em todos os grupos focais, tanto na negociação de programascom o uso do preservativo quanto nas relações íntimas das parc erias amorosas. Porta nto, o estigma se constitui no fa tor preponderante no quadro de dilemas vivido pelas prostituta s e a s toma vulnerá veis com relação às DST.

A Aids é a primeira grande epidemia internacional a ocorrer na Era dos Direitos Humanos. ${ }^{24}$ No campo da Saúde Pública, a nã o-discrimina ção tem sido identific ada como a chave para a integração das questões de direitos humanos com osesforços de prevenção e controle da Aids. Nesse sentido, a incorporação da agenda da prevenção do HIV/Aids vem intensific ando, no caso da luta política do movimento de prostitutas, o diálogo com a sociedade em geral pela conquista de seus direitos.

A luta dasprostitutaspelo exercício efetivo de direitos soma-se a uma série de reivindicações de outros movimentos socia is em to mo da efetivação e garantia dos direitos rep rodutivos e dos direitos sexua is. J unta-se ta mbém às mobilizações dos movimentos de militância de gays e lésb ic as, que buscam a cabarcom as desigualdades socia is e os estig mas rela ciona dos com a s resp ec tiva sidentid a des sexua is.

Segundo Gabriela Silva, uma das lideranças do movimento brasileiro de prostitutas, a o mesmo tempo que a sociedade reconhece a indústria do sexo como uma fonte importante de comércio, por outro lado, castiga as prostitutas por ganhar dinheiro com a atividade sexual. Nesse contexto, são justific a da sa s sistemátic a sexp lora ções das prostitutas, tornando extremamente difícil sua organização por direitos civis e políticos, assim como a segurança profissional. ${ }^{25}$

As a ções rea liza das por associações de prostitutas, muitas vezes em parceria com outras organizações da sociedade civil, visando a criar alternativas para o enfrentamento da epidemia de Aids no contexto desse coletivo, viabilizou, em um primeiro momento, o surg imento de espaços de interação entre as prostitutas, de onde emergiram novas concepções sobre a vida profissional. Parece ter sido possível a identific ação de novas signific ações para a dinâmica do exercício da prostituição.

Talvez, o longo tempo em que o tema esteve 'sob a gua rda' das autorida des so c ia Imente leg itima da s pa ra fa la $r$ sobre ele tenha quase que imperativamente determinado, não só as questões, mas também a forma e o tratamento 
*Agradecimentos: a J oão Marcos Jungmann de Andrade, Ana maria Azevedo, Na ir Brito, Ana Maria Costa, Alexandre Granjeiro, Simone Gueresi, Dirce Guilhem, Gabriela Silva, Altamir Macedo, Liliana Pittaluga, Lília Rossi e Denise Serafim; à Coordenação Nacional de DST/Aids do Ministério da Saúde. que deveriam ser evidenciados no mundo da prostituição. Certamente, é imprescindível que se tenham respostas satisfatórias para os problemas deriva dos das atividades ilegais que circundam a prostituição e as prostitutas, que inquietam e preocupam e que, sobretudo, devem ser debatidos publicamente, pois se constituem em questões para a sociedade, em seu todo.

Por outro lado, o discurso que embasa a demanda por direitos feita pelo movimento de prostitutas sugere a necessidade de uma mirada sobre o tema que permita a aproximação do cotidiano que vem sendo exposto pelas prostitutas, no plano do estigma, das sexualidades e das diferentes formas de se viver o erótico. Talvez seja o momento oportuno para se pensar nisso. Enfim, separaro joio do trigo é o desafio.*

\section{Referências bibliográficas}

BEC KER, Howa rd. Outsiders, Studies in the Sociology of Deviance. $1^{\text {st }}$ Edition. New York: The Free Press of Glencoe, 1963.

BOURDIEU, Pierre. A dominação masculina. 1. ed. Rio de Janeiro: BCD União de Editoras S.A., 1999.

CARRARA, Sérgio. "A AIDS e a história das doenças venéreas no Brasil". In: LOYOLA, Maria Andréa (Org.). AIDS e sexualidade: o ponto de vista das ciências humanas. Rio de J a neiro: Relume-Duma rá /UERJ, 1994. p. 73-108.

FEE, Eliza beth. "Sin Versus Vice: Venereal Disease in Twentieth Century Baltimore." In: FEE, Eliza beth; and FOX, Daniel M. (eds.). AIDS: The Burdens of History. Berkeley: University of Califomia Press, 1988. p. 121-146.

FREITAS, Renan S. Bordel, bordéis: negociando identidades. 1. ed. Petrópolis: Vozes, 1985. GIDDENS, Anthony. A transformação da intimidade: sexualidade, amor e erotismo nas sociedades modernas. 1. ed. São Paulo: Editora UNESP, 1992.

GOFFMAN, Erving. Estigma: notas sobre a manipulação da identidade deteriorada. 4. ed. Rio de Janeiro: Editora Gua nabara, 1988.

GUIMARÃES, Katia; DIAS, Eurípides; COSTA, Ana Maria; ANDRADE, J oão Marcos J. Pesquisa de diagnóstico rápido em DST/Aids para mulheres profissionais do sexo em 9 cidades do Brasil. Brasília, 1997. Rela tório Final. Mimeogra fa do.

GUIMARÃES, Katia; ANDRADE, J oão Marcos J. Pesquisa comércio sexual feminino e a prevenção do HIVIAids no Distrito Federal. Bra sília, 1999. Rela tório Final. Mimeog ra fa do.

GUIMARÃES, Katia; GODOI, Alc inda Maria M.; MERC HÁN-HAMANN, Edgar; ANDRADE, João Marcos J . Avaliação da efetividade das ações de prevenção dirigidas às profissionais do sexo, em três regiões brasileiras. 1. ed. Brasília: Ministério da Saúde do Brasil, Secretaria de Vigilância em Saúde, Programa Nacional de DST/Aids, 2004.

KREISS, J ohan K.; KOECH, Da vy; PLUM MER, Franc is A.; HOLMES, King K.; LG HTFO OTE, Ma rilyn; PIOT, Peter; RONALD, Allan R.; NDINYA-ACHOLA, J osia h O.; D'COSTA, Lourdes J .; ROBERTS, Pacita; NGUGI, Elisabeth N.; and QUINN, Thomas C. "AIDS Virus Infection in Nairobi Prostitutes: Sp rea d of the Ep idemic to East Africa." The New England Journal of Medicine, v. 314, n. 7, Feb. 1986, p. 414-418. 
MANN, J onatha n M.; and TARANTO LA, Da niel J. M. "From Epidemiology to Vulnera bility, to Human Rights." In: MANN, J ona than M.; and TARANTOLA, Daniel J. M. AIDS in the World II. Global Dimensions, Social Roots and Responses. $1^{\text {st }}$. Ed ition. New York: Oxford University Press, 1996. p. 427-476.

MERC HÁN-HAMANN, Edgar; EKSTRAND, Ma ria; HUDES, Estie; a nd HEARST, Norma n. "Preva lence and Correlates of HIV-Related Risk Behaviors among Adolescents at Public Schools in Brazil." Aids and Behavior, v. 6, n. 3, 2002, p. 283-293.

NUSSBAUM, Martha. "Pela razão ou preconc eito: ga nhar dinheiro com o uso do corpo". In: THEMIS. Direitos sexuais. 1. ed. Porto Alegre: Themis, 2002. p. 13-55.

PARKER, Richard G.; DANIEL, Herbert. Aids: a terceira epidemia. 1. ed. Rio de Janeiro: Ed itora Iglu, 1991.

PARKER, Ric hard G. Construção da solidariedade: Aids, sexualidade e políticas no Brasil. 1. ed. Rio de Ja neiro: IMS-UERJ, ABIA, Relume Duma rá, 1994.

PASSOS, Carlos Artur K. Indicadores, ONGs e cidadania: contribuições sociológicas e metodológicas. 1. ed. Curitiba: Pla ta forma Contra partes Novib/GTIndic a dores, 2003.

PIOT, Peter; PLUMMER, Fra nc is A.; REY, Ma rie-Anne; NGUGI, Elisa beth N.; ROUZO UX, C hristine; NDINYA-ACHO LA, J osiah O.; VERACAUTEREN, Gaby; D'COSTA, Lourd es J.; LAGA, Ma rie; NSANZE Herbert; FRANSEN, Lieve; HAASE, David; VAN DER GROEN, Guido; BROUHAM, Robert C.; RONALD, Allan R.; BRUN-VÉNIZET, Fra nç o ise. "Retrospec tive Seroepid emiology of AIDS Virus Infection in Na irobi Populations." Journal of Infectious Diseases, v. 155, n. 6, jun. 1987, p. 1108-1112.

PORTELLA, Ana Paula. Rotas de exclusão: tráfico de mulheres e exploração sexual em Pernambuco. 1. ed. Recife: SOS Corpo - Gênero e Cidadania, 2003.

RAGO, Marga reth. "Prostituição e mund o boêmio em São Paulo (1890-1940)". In: PARKER, Richard G.; BARBOSA, Maria Regina (Orgs.). Sexualidades brasileiras. 1. ed. Rio de J a neiro: Relume Duma rá, 1996. p. 51-60.

SERAFIM, Denise; SILVA, G a briela; SANTANA, J o sé La mir; GUIMARÃES, Ka tia; PITTALUG A, Lilia na; DOMING UES, Roberto C. Profissionais do sexo: documento referencial para ações de prevenção das DST e da Aids. 1. ed. Bra sília: Ministério da Saúde, Sec retaria de Polític as de Saúde, Coordenação Nacional de DSTe Aids, 2002.

VIANNA, Ad ria na; LAC ERDA, Pa ula. Direitos e políticas sexuais no Brasil: o panorama atual. 1. ed. Rio de Janeiro: Centro Latino-americano em Sexualidade e Direitos Humanos/ Instituto de Medicina Social (IMS)0, 2004. Coleção Documentos.

[Recebido em dezembro de 2004 e aceito para publicação em julho de 2005]

\section{Commercializing Fantasies: Social Representations of Prostitution, Dilemmas of the Profession and the Construction of Citizenship}

Abstract: This article presents facts, perceptions and social representations on the daily life of female commercial sex workers (FCSW). We evaluated 8 educational intervention programs on STDIAIDS addressed to FCSW in cities of southern, south-eastern and north-eastern Brazilian regions. In those places, we conducted in-depth interviews and focal groups. Results indicate that the representation of a woman who sells her body is resignified as the performance of erotic fantasies. Possibilities of greater autonomy are hampered by discrimination and psychological tension. Client and police-driven violence were remarkable. Condom use plays a relevant role in sex negotiation but it is neglected when relationships involve affection or as a result of competition. We conclude, from the perspective of autonomy, that FCSW's autonomy is limited by social class, economical crisis and stigma, leading to discrimination, violence and STD/HIV contagion risk.

Key Words: commercial sex, human rights, HIVIAids, vulnerability, social representations. 